\title{
Boko Haram Insurgency and the 2015 General Elections in Nigeria
}

\author{
Emmanuel Ikechi Onah \\ Department of Political Science \\ University of Lagos, Nigeria \\ eonah@unilag.edu.ng
}

DOI: https://doi.org/10.32890/jis2015.11.2

\begin{abstract}
This is a study of the Boko Haram insurgency in Nigeria, and how it affected the 2015 General Elections in the country. The Boko Haram is a Muslim fundamentalist sect founded in 2002, but the insurgency it mounted in Nigeria in 2009 has dovetailed into politics. By the time of the 2015 elections in Nigeria, the insurgency had become the foremost political issue in the country. Boko Haram was central in the campaigns for the elections, and the fortunes of the political parties and their candidates literally depended on where they stood concerning the Boko Haram matter. Interestingly, the elections also affected the fortunes of Boko Haram as the incumbent government at the time had to come out in full force against the sect as a way of shoring up its chances at the polls. Since after the polls, the viability of the insurgency has considerably reduced, although the sect continues to pose a threat to the country. This paper argues that beyond victory in the battlefield, the government of Nigeria must also improve on its governance practices in order to remove the socio-economic conditions that help to sustain Boko Haram and other such militant groups in Nigeria.
\end{abstract}

Keywords: Boko Haram, insurgency, Nigeria, politics, general elections 2015.

\section{Introduction}

No other issue probably shadowed the 2015 general elections in Nigeria more than the Boko Haram insurgency in the northern part of the country. Although the insurgency started much before President Goodluck Jonathan assumed office in Nigeria, immediately he did, the Boko Haram phenomenon became part and parcel of the political calculations in the country. Part of the reasons for Boko Haram assuming this importance can be traced to the controversial circumstances under which President Jonathan came into office in 2010. His assumption of office followed the death of President Musa Yar' Adua in office in 2009 (Adeniyi, 2011). At the time of President Yar'Adua's death, there existed a zoning arrangement in the ruling Peoples Democratic Party, by which the presidency was to rotate in the first instance, between the North and the South of the country. The North of the country includes 19 of the thirty-six states in Nigeria, while the South includes 17 states. 
It was on account of this arrangement that Olusegun Obasanjo, a Southerner, was elected in 1999 as President, and he stayed in office for two tenures of eight years (Ayoade, 2011). In 2007, President Yar'Adua, a Northerner, succeeded Obasanjo in office. However, less than 3 years into his first tenure of four years, President Yar'Adua died. By the existing arrangement within the ruling party in Nigeria, another political actor of northern origin was supposed to be picked in replacement of President Yar'Adua, to complete the remaining 5 years of the 8-year northern presidential tenure. But citing the "precarious situation" of the country at the time, a 'doctrine of necessity' was formulated by the country's leaders to enable the then Vice President Jonathan to take over as President (Adeniyi, 2011).

It is alleged that dominant northern interests felt that their region was shortchanged by this arrangement, and were not ever comfortable with the situation. Shortly after the succession, the Boko Haram violence degenerated into a full-blown insurgency. This sudden escalation has fuelled suspicions that the Boko Haram phenomenon was invented by the northern establishment for the purpose of registering their displeasure with the Jonathan presidency (Suleiman, 2012: pp. 20-6). The argument has been that the Boko Haram group was adopted subsequently as a cover by the elite and politicians of the North to fight their political and sectional interests. Government's attitude and pronouncements concerning the Boko Haram phenomenon also reinforced the arguments that the insurgency was a northern elite contraption. Government maintained that Boko Haram had 'sponsors' who were only out to intimidate or blackmail the government.

This has never been substantiated though, especially because Boko Haram came into existence much before President Yar'Adua's death. Prominent Northerners have actually denied these accusations of involvement with the Boko Haram sect, and have maintained that government deliberately did not do enough to curb the Boko Haram menace, as a way of punishing the region for its presumed opposition to the Jonathan presidency (Odebode, Alachenu, Akasika, \& Ubabukoh, 2014). Some of them have even argued further that the above (southern) views and (government) position were possibly counter-blackmail, to force the North to accept the political realities of a southern, Jonathan-led presidency in Nigeria beyond 2015 (Babalola, 2014, p. 9).

Notwithstanding, once President Jonathan took office, the feeling gained ground that Boko Haram was the handiwork of the northern political elite. Some analysts have actually argued that Boko Haram was a tool in the hands of the North for the purposes of the 2015 presidential contest in Nigeria. The belief was that either the North was using Boko Haram to distract President Jonathan so that in the end, the President would not have done enough to merit a second term in office in 2015, or, that Boko Haram was a bargaining tool in the hands of the North to force the President not to seek re-election in 2015 (Ogbonnaya, 2011). 2015 was the year that President Yar'Adua would have handed over power had he lived till the end of his tenure, and in 2010, when it became obvious that Jonathan was plotting to take over, some elements in the North had agreed, on the condition that the President will not stay in office beyond 2015 . 
The view that government was not doing enough to fight the Boko Haram insurgency soon became widespread in the North. This was especially so because the sect grew in strength over time and engaged in wanton destruction of lives and properties within the region. In fact, at a stage, members of Boko Haram were reputed to operate at will and for long periods at a time unchallenged. On such occasions, the group would even move in convoys while going for their operations, and members of security agencies who happened to be on their paths were known to have scampered away for safety (Zounmenou \& Kane, 2014). Ultimately, this situation produced backlashes in the North, as the people increasingly felt disenchanted with the government, especially in the run-up to the 2015 elections. It is the impact of this disenchantment, and the ultimate effect of the Boko Haram insurgency generally on the 2015 general elections that this paper seeks to study.

\section{Origins of the Boko Haram Insurgency in Nigeria}

The Boko Haram crisis is the latest in a long line of religious-inspired political violence that has arisen in the northern part of Nigeria. In fact, the North has been the theatre of so much religious crises. According to Onah (2014), the reason for this can be found in the country's political system and goes back to the history of the northern region. A combination of colonial and post-colonial policies in the North imbued Islam with the colouration of state religion. In the pre-colonial time, Uthman dan Fodio had conquered the area on the basis of Islam, which subsequently became the religion of state in the empire that he established (Dudley, 1968). This was the situation when the colonialists came to the area. Although, the British conquered the emirates, they largely left the emirs and their administrations intact in a system of indirect rule which enabled the emirs to continue as religious and political leaders (Kirk-Greene, 1965).

Islam thus, continued to be the basis of government throughout the colonial period. The British, at independence, again handed over power to the Northern feudalists, and politics and administration continued largely to be mixed with religion as before, with the Sharia still prominent in the scheme of things (Whitaker, Jr., 1970). In the years since independence, political leadership in the North has therefore continued to be closely associated with religious leadership. The result has been that the Muslim faithful have largely not been able to distinguish between corruption among the political leadership and religious corruption. These faithful, especially the more fundamental ones, have therefore, seen it as their duty to oppose all such corruption, including in the political arena (Onah, 2014). It is in this light that the various religious violence that have gripped the country can clearly be understood as actually political violence.

The first such religious-cum-political violence in recent times was the Maitatsine Riots of 1980-87 (Lubeck, 1986). These riots, which first broke out in Kano in 1980 before spreading to towns like Jimeta, Gombe, and Funtua between 1982 and 1987, was led by the fundamentalist Muslim cleric, Mohammed Marwa. The riots itself derived its name from 
the curse which Marwa placed on corrupt leaders who would not listen to his preaching (Maitatsine - followers of he who curses). In the end, the Maitatsine movement was crushed, but it is significant that the disturbance reached its height in the early 1980s when there was widespread disillusionment over the corruption in the country's Second Republic. Between 1996-1997, it was the turn of the Shiite attacks, led by Ibrahim El Zak-Zaky (Udoidem, 1997, p. 153). The Shiite movement preached against political corruption in the country, which at the time, was under military rule. It is also significant that this was occurring at the period when political corruption under the military was at its height with General Abacha as Head of State of the country.

The Fourth Republic took off in 1999 with high expectations and hopes. It was not long however, before it became apparent that corruption in the country has not only continued to be business as usual, but that it was actually becoming intractable. In fact, notwithstanding the return to democracy in 1999, Nigeria still placed last among the 90 countries surveyed by Transparency International in their Corruption Perceptions Index (CPI) in 2000. Even when the number of countries surveyed increased to well over 100, the country only moved up by one spot to place as the second to the last country after Bangladesh in the CPI for 2001, 2002 and 2003 (Transparency International, 2013). According to Onah (2014), the Muslim faithful had largely felt that the situation was possible only because thieving officials could not be held accountable in any meaningful way by the existing common laws of the land.

This was why the introduction of Sharia laws by several state governments in the North between 2000 and 2002 was accompanied by widespread joy in the region. This however, ultimately only led to disappointment among the people when the corrupt practices of the emergent civilian dispensation did not stop but instead became more entrenched. The riots that followed the 2002 Sharia laws therefore reflected the misplaced hopes of a majority of the people that politics would finally be run according to divine injunctions (Harunah, 2002). The Boko Haram phenomenon was the direct result of these misplaced hopes (Onah, 2015, p. 68). The group known as Boko Haram was formed in 2002 in Maiduguri, capital of Borno State in northern Nigeria by Mohammed Yusuf, a Muslim cleric who had been associated with radical Islamic youth movements in the 1990s (Sergie \& Johnson, 2014).

The group is officially named the Congregation of the People of Tradition for Proselytism and Jihad or Jamaat Ahl as-sunnah lid-da'wa wal-Jihad. It is however, generally known by its Hausa language nickname of Boko Haram, which literally means 'western education is sin.' The average pious Northern Moslem views Christianity and its Western education with suspicion and sees both as purveyors of corruption or sinfulness. The group's base at the time of founding was a religious complex in Maiduguri that housed a mosque and an Islamic school, to which many underprivileged families sent their children for instruction (Chothia, 2012). The aims of the group included the establishment of the Sharia as the supreme law of the society; putting an end to political and religious corruption, and abolishing all western cultural influences on the society, including the western educational system (Onah, 2014). In 2004, the group's headquarters complex was relocated to Yusuf's home town of Kanamma 
in Yobe State. It was around this time also that Yusuf started speaking out against government highhandedness and political corruption, which served to attract numerous unemployed youths to his fold (Guttschuss, 2012). Increasingly, Yusuf's preaching attacked the northern Muslim establishment and government officials for their un-Islamic, corrupt practices. This was even more so after the widespread rigging of the 2007 general elections in the country. Then in 2009, a new law was brought into effect by the Bauchi State government compelling all users of motorbikes in the state to wear helmets for their safety. This law was rejected by the Boko Haram group. Attempts by the state government in July of that year to enforce the law finally brought members of the group face to face with the police.

The disturbance was quickly suppressed by the police, but the highhandedness of the police in handling this matter soon led to an armed uprising by the group (Sergie and Johnson, 2014). The uprising quickly spread to the neighbouring states of Borno, Yobe and Kano. The uprising was finally quelled by the army, but not before more than 800 people (by official account) had died. Hundreds of Boko Haram members, including several leaders of the sect, were arrested and detained at police headquarters in Maiduguri. About 17 of these leaders, including Yusuf himself and his father-in-law, were subsequently killed by the police in the full glare of television cameras (Katsina, 2011). It was in the aftermath of the 2009 uprising that the Boko Haram sect blossomed into a full-fledged armed insurrection in the country.

Following Yusuf's death, Abubakar Shekau took over as leader (Katsina, 2011). In the face of a continuing crackdown by government, the group apparently reassessed its position and eventually adopted violence as a means of pursuing its objectives. Boko Haram violence was thus the culmination of the group's grievances against the Nigerian state and its organs and officials (Sergie and Johnson, 2011). These grievances included poor governance and increasing corruption of government officials (as reflected in their preachings), as well as the group's harsh treatment in the hands of government agencies, particularly the police. The crackdown of 2009 apparently proved to the members that their concerns had fallen on deaf ears. Left with no other options then, the group embarked on violence.

\section{Violent Activities of the Boko Haram in Nigeria}

The first violent act by the Boko-Haram group was carried out on 7 September, 2010 when it staged a prison break in Bauchi in which over seven hundred inmates were freed. Many of the freed inmates were members of the sect. In December of that same year, a market in Abuja, Nigeria's capital was bombed by the Boko Haram, killing several people. This violence continued in several forms, including bombing of churches, government buildings, police stations, and the United Nations building in Abuja; prison breaks, assassinations, shootings and hostage taking. Whole villages have been attacked and several people killed. Later, the group added attacks on schools, which led to numerous killings of school children and the abduction of several others (Sergie \& Johnson, 2011). 
As time went on, attacks by the group became very audacious. In their attack on a federal government secondary school in Buni Yadi, Yobe State, the operatives of the group were reported to have come in eighteen buses and spent more than 7 hours, killing more than 50 persons and burning down the entire school without any challenge whatsoever from security forces (Zounmenou \& Kane, 2014). On the night of 14-15 April, 2014, the group attacked the Government Girls Secondary School, Chibok, in Borno state. Over 200 school girls were abducted from the school by the group, and they have not been rescued more than one year after. The girls were reportedly loaded into two trucks and transported away unchallenged, after burning down the entire school buildings (BBC News, 2014).

Overall, it is estimated that the conflict has consumed several thousands of lives, while properties worth several millions of dollars have been lost. In 2012 alone, Boko Haram accounted for 1,386 deaths in 546 attacks, and in 2013, the group was involved in 213 attacks with over 1000 deaths (START, 2013). By 2014, the group is believed to have killed over 12,000 civilians and security personnel (Premium Times, 2014). As far back as 2012, life in the parts of northern Nigeria where the group was most active had literally come to a standstill. But even as the situation continued to deteriorate, the attitude of the Nigerian government to the menace remained lackadaisical. At first, government adopted an attitude of dismissal. As the president asserted at the time, the Boko Haram phenomenon was a phase in the nation's life that will soon pass away. When the sect apparently refused to disappear, the government promised to wipe them out in a short while. The government then put up some feeble efforts at combating the violence, which ultimately did not produce much.

Government even tried other means, including attempts at dialogue, and hints at the granting of amnesty to members of the group, in the hope that they would give up arms. It was when all the above failed that government finally tried to take the offensive. On 14 May 2013, the president declared a state of emergency in the three most affected states of Borno, Yobe and Adamawa. Government then assembled a Joint Task Force (JTF) of military personnel to engage the Boko Haram in full combat (Sergie \& Johnson, 2014). The JTF was very effective at first, and soon drove the sect out of the cities. The group however subsequently apparently entrenched themselves in the rural areas, from where it proved difficult for the government forces to dislodge them. Soon after the Boko Haram group settled themselves in the rural areas, they started occupying territory. Government kept sealed lips on this at first, but only until prominent northerners started speaking up.

A number of northern leaders soon openly accused the federal government of giving up Nigerian territory to Boko Haram, claiming that even some local government areas were under the administration of the group (News Express, November 4, 2015). It was then that government cleared the air, but blamed the situation on the difficulties it said it was having in procuring arms and equipment for the prosecution of the war. As this was happening, the Boko Haram group declared a caliphate over the territories that it controlled in Nigeria. 
Subsequently, the group severed its links with Nigeria and pledged allegiance to the Islamic State (IS), which promptly accepted the affiliation and named the area the Islamic State of West Africa Province (Chothia, 2015).

Table 1

Some of the Violent Activities of Boko Haram in Nigeria between July 2009 to January 2015

\begin{tabular}{|c|c|c|c|}
\hline $\mathbf{S} / \mathbf{N}$ & DATE & Incidents (Nature and Location) & Casualty Figures \\
\hline 1 & September 7, 2010 & $\begin{array}{l}\mathrm{BH} \text { attacked a prison in Bauchi and freed } 700 \text { inmates } \\
\text { including former sect members }\end{array}$ & 5 guards killed \\
\hline 2 & December 28, 2010 & $\begin{array}{l}\text { BH claims responsibility for the Christmas eve bombing in } \\
\text { Jos }\end{array}$ & 38 people killed \\
\hline 3 & May 29, 2011 & Bombing of Army Barracks in Bauchi and Maiduguri & 15 people killed \\
\hline 4 & June 26, 2011 & Bomb attack on a bar in Maiduguri & 25 people killed \\
\hline 5 & August 16, 2011 & Bombing of the United Nations office complex in Abuja & $\begin{array}{l}\text { Over } 34 \text { people } \\
\text { killed }\end{array}$ \\
\hline 6 & December 25, 2011 & $\begin{array}{l}\text { Bombing of St. Theresa's Catholic Church, Madalla, Niger } \\
\text { state }\end{array}$ & $\begin{array}{l}\text { Over } 46 \text { people } \\
\text { killed }\end{array}$ \\
\hline 9 & January 21, 2012 & Multiple bomb blasts in Kano city & $\begin{array}{l}\text { Over } 185 \text { people } \\
\text { killed }\end{array}$ \\
\hline 10 & February 15, 2012 & $\begin{array}{l}\text { Attack on Katon Karfe prison, Kogi State, in which } 119 \\
\text { prisoners were freed }\end{array}$ & 1 Warder killed \\
\hline 11 & February 19, 2012 & $\begin{array}{l}\text { Bomb blast near Christ Embassy Church in Suleija, Niger } \\
\text { State }\end{array}$ & $\begin{array}{l}5 \text { people } \\
\text { killed }\end{array}$ \\
\hline 12 & February 26, 2012 & Bombing of Church of Christ of Nigeria, in Jos & $\begin{array}{l}2 \text { people killed } \\
\text { and } 38 \text { injured }\end{array}$ \\
\hline 13 & March 8, 2012 & $\begin{array}{l}\text { An Italian, Franco Lamolinara, and a Briton, Christopher } \\
\text { McManus, expatriate staff of Stabilini } \\
\text { Visinoni construction company, abducted since mid-2011, } \\
\text { were killed by a splinter group of BH }\end{array}$ & 2 people killed \\
\hline 14 & March 11, 2012 & Bombing of St. Finbarr's Catholic Church, Rayfield, Jos & $\begin{array}{l}11 \text { people killed } \\
\text { and many injured }\end{array}$ \\
\hline 15 & April 26, 2012 & Bombing of three media houses in Abuja and Kaduna & $\begin{array}{l}8 \text { people killed } \\
\text { and many injured }\end{array}$ \\
\hline 16 & April 29, 2012 & Attack on Bayero University, Kano & $\begin{array}{l}16 \text { people killed } \\
\text { and many injured }\end{array}$ \\
\hline 17 & April 30, 2012 & Bomb explosion in Jalingo & $\begin{array}{l}11 \text { people killed } \\
\text { and several others } \\
\text { wounded }\end{array}$ \\
\hline 18 & $\begin{array}{l}\text { September 23, } \\
2012\end{array}$ & $\begin{array}{l}\text { A suicide bomber attacked St. John's Catholic Church in } \\
\text { Bauchi }\end{array}$ & $\begin{array}{l}2 \text { persons killed } \\
\text { and over } 48 \\
\text { injured }\end{array}$ \\
\hline
\end{tabular}




\begin{tabular}{|c|c|c|c|}
\hline $\mathbf{S} / \mathbf{N}$ & DATE & Incidents (Nature and Location) & Casualty Figures \\
\hline 19 & December 5, 2012 & Attack in Kano City on civilians in a bus & $\begin{array}{l}2 \text { policemen killed } \\
\text { and several others } \\
\text { injured }\end{array}$ \\
\hline 20 & March 23, 2013 & $\begin{array}{l}\text { Attacks in Kano, Adamawa, Borno. Banks, police stations } \\
\text { and a prison torched }\end{array}$ & $\begin{array}{l}128 \text { killed and } \\
\text { several others } \\
\text { injured }\end{array}$ \\
\hline 21 & April 12, 2013 & Attack on Yobe police & $\begin{array}{l}4 \text { policemen and } \\
5 \text { sect members } \\
\text { killed }\end{array}$ \\
\hline 22 & April 19,2013 & $\begin{array}{l}\text { Boko Haram battles with multinational security forces from } \\
\text { Niger, Nigeria and Chad in the city of Baga in Borno State }\end{array}$ & $\begin{array}{l}200 \text { people dead, } \\
\text { including many } \\
\text { civilians }\end{array}$ \\
\hline 23 & June 22, 2013 & Attack on Barma town, Yobe state & $\begin{array}{l}40 \text { police men, } 13 \\
\text { prison warders, } \\
3 \text { soldiers and } \\
\text { several other } \\
\text { civilians killed }\end{array}$ \\
\hline 24 & September 17, 2013 & $\begin{array}{l}\text { Boko Haram gunmen dress in military uniforms and stage a } \\
\text { fake checkpoint near Benisheik in Borno, executing travelers } \\
\text { and burning vehicles }\end{array}$ & $\begin{array}{l}\text { At least } 143 \\
\text { people dead }\end{array}$ \\
\hline 25 & September 29, 2013 & Attack on Yobe State College of Agriculture in Gijba & 7 students killed \\
\hline 26 & January 26, 2014 & Attack on a market in Kawuri in Borno & $\begin{array}{l}\text { At least } 45 \text { people } \\
\text { are killed }\end{array}$ \\
\hline 27 & February 11, 2014 & $\begin{array}{l}\text { Suspected Boko Haram militants torch houses in the village } \\
\text { of Konduga }\end{array}$ & $\begin{array}{l}\text { At least } 23 \text { people } \\
\text { are killed }\end{array}$ \\
\hline 28 & April 14,2014 & $\begin{array}{l}\text { Boko Haram militants attack a boarding school in Chibok in } \\
\text { Borno }\end{array}$ & $\begin{array}{l}\text { Approximately } \\
276 \text { teenage girls } \\
\text { kidnapped }\end{array}$ \\
\hline 29 & May 13, 2014 & $\begin{array}{l}\text { Hundreds of Boko Haram militants storm three villages in the } \\
\text { state of Borno. Villagers resist }\end{array}$ & $\begin{array}{l}\text { More than } 200 \\
\text { Boko Haram } \\
\text { fighters killed }\end{array}$ \\
\hline 30 & June 3-4, 2014 & Raids by Boko Haram Islamic militants in the state of Borno & $\begin{array}{l}\text { Hundreds of } \\
\text { people are killed. } \\
\text { Death toll put at } \\
400 \text { to } 500\end{array}$ \\
\hline 31 & June 7-8, 2014 & $\begin{array}{l}\text { Suspected Boko Haram militants attack the northeastern } \\
\text { Nigeria village of Garkin Fulani over a weekend }\end{array}$ & $\begin{array}{l}\text { At least } 20 \text { young } \\
\text { women kidnapped }\end{array}$ \\
\hline 32 & June $18-22,2014$ & $\begin{array}{l}\text { Boko Haram militants hold the village of Kummabza in } \\
\text { Borno state, northeastern Nigeria, hostage for four days }\end{array}$ & $\begin{array}{l}\text { More than } 60 \\
\text { females, including } \\
\text { children, } \\
\text { abducted, and } 30 \\
\text { men killed }\end{array}$ \\
\hline 33 & July 17-20, 2014 & Boko Haram raids the Nigerian town of Damboa & $\begin{array}{l}66 \text { residents killed } \\
\text { and more than } \\
15,000 \text { flee the } \\
\text { town }\end{array}$ \\
\hline
\end{tabular}




\begin{tabular}{|c|c|c|c|}
\hline $\mathbf{S} / \mathbf{N}$ & DATE & Incidents (Nature and Location) & Casualty Figures \\
\hline 34 & January 3,2015 & $\begin{array}{l}\text { A multi-day raid begins, where hundreds of Boko Haram } \\
\text { gunmen seize the town of Baga and neighboring villages in } \\
\text { northern Nigeria, as well as a multinational military base, } \\
\text { leaving bodies scattered everywhere }\end{array}$ & $\begin{array}{l}\text { As many as } 2,000 \\
\text { people feared dead }\end{array}$ \\
\hline 35 & January $10-11,2015$ & $\begin{array}{l}\text { Explosives strapped to a girl are detonated in Maiduguri at } \\
\text { a marketplace screening checkpoint. Two suicide bombs, } \\
\text { strapped to girls, are detonated in a mobile phone market in } \\
\text { Potiskum }\end{array}$ & $\begin{array}{l}\text { At least } 20 \\
\text { are killed and } \\
18 \text { injured in } \\
\text { Maiduguri. } \\
\text { At least three } \\
\text { are dead and } \\
43 \text { injured in } \\
\text { Potiskum }\end{array}$ \\
\hline
\end{tabular}

Sources: Okoro, 2014: 111-3; CNN Library, 2015.

\section{Boko Haram Insurgency and the 2015 General Elections in Nigeria}

The information that Boko Haram was occupying Nigeria territory came just as the country was entering into the period of campaigns for the 2015 general elections. President Jonathan had been re-nominated by his party, the People's Democratic Party (PDP), as presidential candidate for the elections. The fact of Boko Haram occupying Nigerian territory immediately became a campaign issue, and the opposition drummed it up as a demonstration of the incompetence of President Jonathan. Coupled with the already ingrained feeling that President Jonathan was anti-North, the argument soon caught up, and the ruling party's fortunes nose-dived, particularly in the northern states. In fact, as the campaigns heated up, the attitude of the people to the ruling party in the North even became hostile. The president's campaign train was actually stoned in a number of the northern states. In many other northern states, the president was booed by crowds at campaign rallies (Owuamanam, Olalekan, \& Bakam, 2015). In contrast, the main opposition candidate, General Muhammadu Buhari of the All Progressives Congress (APC), drew mammoth crowds at rallies across the country, especially in the North, where his appeal was boosted by his presumed capabilities to resolve the Boko Haram phenomenon.

Sympathy for the president was rife across the southern states, particularly in the Southsouth and the South-east geo-political zones. Here, President Jonathan's supporters, had all along believed that Boko Haram was created by the northern leadership and it was therefore the prime responsibility of the northern leadership, not the president, to tackle the matter. The sharply divided views about the President nearly polarized the campaigns along the north-south divide, although the opposition campaign continued to be strong in many southern states. Subtle attempts were even made, especially by the foot soldiers of the president, to draw religion into the fray, as the north-south divide in Nigeria conforms roughly to a muslim-Christian divide (Agunweze, 2015, p. 58). This was however, largely unsuccessful as many important Christian religious leaders refused to take up the chant. 
As the elections drew close, it became clear that President Jonathan and his party were not faring well altogether. Opinion polls showed that the ruling party will lose if elections were held as scheduled. Even the opposition knew this and became very confident (Daily Sun, March 9, 2015, p. 13). They even warned that they will simply form a parallel government if the ruling party tried to manipulate the results of the elections. Faced with imminent defeat, the government then devised a strategy to postpone the elections so as to give the ruling party more time to reach out to the people. The plan was interestingly hinged on Boko Haram. Government argued that it was not possible to hold the elections as scheduled in those parts of the North where Boko Haram was most active, especially in the three states of Adamawa, Yobe and Borno where the sect controlled a number of local government areas. The national electoral body continued to promise that it was ready for the elections as scheduled (Mohammed, 2015), and argued that it could take a number of options, including rescheduling the elections in the twelve local government areas so affected. The country has a total of 774 local government areas. The security forces, particularly the military, however, insisted that they could not guarantee the security of electoral personnel and materials in the entire north-east states. They advised that the elections be postponed by six weeks to enable them to launch an operation against the Boko Haram which they had planned to start on 14 February, the day the presidential election was also scheduled to be held. It was based on this advice that the electoral commission finally announced a postponement of the elections from February 14 and February 28 to March 28, 2015 and April 11, 2015 respectively (Sotubo, 2015).

This postponement did not go down well with the majority of Nigerians, but the parties, especially the ruling PDP, immediately went back to the campaign trail. Expectedly, the military launched its operation against Boko Haram. Aided by the other countries in the joint operation and even mercenaries from South Africa and countries of the former Soviet Union, the military operation was largely effective and Boko Haram was driven from most of their locations (Oladipo, 2015). As the six week window was coming to an end, the military argued that though they had recovered most of Nigerian territory from the sect, the situation was not yet right for elections to be held in the affected areas. New attempts were then made to postpone the elections again (Adetayo, 2015), but the Independent National Electoral Commission (INEC) clearly was not in agreement, and insisted that it will not consider any further postponements (Mohammed, 2015).

Eventually, the elections were held on the rescheduled days. The INEC even took the risk to hold elections in the liberated local government areas. Generally, voting was peaceful and apart from a few bombings attributed to Boko Haram on the day of the presidential election, security was high. True to expectations, the opposition won. In the North-east, especially in the most affected areas, the opposition cleared the votes. This was true for almost all the north, as well as in many other parts of the country, with the exception of the south-south and the south-east geo-political regions, where President Jonathan was voted massively. The votes of these two zones in the South however, could not save the president, and his challenger, Mohammadu Buhari was declared President-elect. 


\section{Boko Haram Insurgency in the Aftermaths of the 2015 Nigerian Elections}

The Boko-Haram insurgency was thus, a big factor in the 2015 Nigerian general elections. It served to turn the sentiments against the incumbent government. At a time during the elections, it also served the government as a tool for manipulating the election arrangements in the hope to snatch victory at the polls. In the end, it was the opposition that cashed in on the situation and won the elections. After the polls, government did not relent in the war against the insurgency. Government forces continued to notch up victories against Boko Haram, and within a few weeks of the election, virtually all Nigerian towns previously held by Boko Haram had been retaken (Soriwei, 2015). It became clear that the potency of Boko Haram as an effective fighting force has been substantially destroyed (Kilete, 2015). The group's last known bastion in the Sambisa forest of the Lake Chad area was finally retaken by Nigerian government forces.

Nevertheless, Boko Haram has continued to remain a big security threat in Nigeria. Not long after the capture of Sambisa, the sect recaptured the strategic town of Marte in Borno state (Audu, 2015). Recently, the sect carried out a major assault on the capital of Borno state, Maiduguri, in which fighters belonging to the sect battled government forces for close to two days, with several casualties on both sides as well as civilian casualties (Idowu, 2015). Since then however, the sect seems to have changed strategy, presently using guerrilla hit and run tactics as well as suicide bombings. There have been several such suicide bombings in the recent past, in which hundreds of people have died. The new government of President Buhari continues to promise that it will defeat the sect, and has been reportedly working out arrangements with the other affected countries of Chad, Niger, and Cameroon, for effective counter-action (Niger Reporters, 2015). In fact, Boko Haram was one of the top issues discussed during the recent visit of President Buhari to America, during which President Obama promised that the United States will actively support the anti-Boko Haram effort (Transparent Nigeria, 2015).

Beyond fighting power however, there are doubts about government's capability to win the war on the field if the root causes of the conflict are not effectively addressed. Analysts have pointed out that the real causes of the Boko Haram phenomenon are not to be located in religion or electoral politics, but in the socio-economic conditions of the North occasioned by the failure of governance in the country (Okoro, 2014). It is the people's disenchantment with the lack of inclusiveness in the country, especially in the face of extreme poverty, particularly in the North, that is at the root of the Boko Haram menace (The Punch, 2014, p. 3). Analysts have said that the threat from Boko Haram will disappear only if Nigeria's government manages to reduce the Northern region's chronic poverty as well as build an educational system that will gain the support of local Muslims (Chothia, 2015). That is why it is now advocated that the present government in Nigeria must look beyond victory on the battle field if it must resolve the Boko Haram phenomenon sustainably. This has even been echoed by the American Secretary of State, who during Buhari's visit to America, stressed that the Boko Haram threat cannot be defeated by military means only, but by ensuring inclusive governance and the provision of basic amenities to the people (Ochai, 2014). 


\section{Conclusion}

The Boko Haram insurgency was at the centre of the 2015 general elections in Nigeria. It ultimately was decisive in enabling the opposition defeat the government in that election. Interestingly, that election also proved decisive in turning the tide against the insurgency. It was in the attempt to regain the momentum in the campaigns that government finally resolved to confront Boko Haram in strength. In the aftermaths of the 2015 elections, it can be said that it is not conceivable that Boko Haram will likely recover the initiative in its fight against the Nigerian state, especially with the promise and determination of the new government in Nigeria to completely defeat the insurgency. It may only be a matter of time before ultimately Boko Haram is defeated.

When the insurgency is finally defeated, it can even be said that Boko Haram was the architect of its own end. It simply overreached itself. Its declaration of a caliphate over parts of Nigerian territory was certainly one insult too many to the giant country. Then, not heeding the wisdom that "the tail of even a sleeping lion must not be touched," the sect decided to extend its attacks to Nigeria's neighbours- not even one of the countries at a time but the whole four of them! Finally, when Boko Haram decided to align with the ISIS, it was only drawing the sane world into the conflict in Nigeria - even the United States that had earlier cut off its military cooperation with Nigeria on the insurgency was soon back to the fray. It is expected that the end is near for Boko Haram, and that the government in Nigeria has all it takes to finally abolish the conditions that make groups such as Boko Haram possible in Nigeria.

\section{References}

Adeniyi, O. (2011). Power, politics and death: A Front-row account of Nigeria under the late President Yar'Adua. Lagos: Kachifo Ltd.

Adetayo Olalekan. (2014, April 3). World leaders must identify terror sponsors-Jonathan. The Punch, 7.

Adetayo, O. (2015, March 17). Jonathan, security chiefs to discuss anti-terror war, polls. Punch, p. 3.

Agunweze, C. (2015, March 9). Politicians with blood-stained hands won't win election Uzorma. Daily Sun, p. 58.

Audu, O. (2015, May 15). Boko Haram recaptures Borno border town. Premium Times. Retrieved from http://www.premiumtimesng.com/news/top-news/183039

Ayoade, J. (2011). Zoning of political offices in Nigeria: Patriotism or plunder? In Ayoade, J. A., \& Adeoye A. Akinsanya (Eds.). Nigeria's critical election, 2011. Plymouth, UK: Lexington Books.

Babalola, A. (2014, April 29). Boko Haram: Politicians stoking insurgency, says Okonjo Iwuala. The Punch.

Chibok Abductions in Nigeria: More than 230 seized. BBC News. (2014). Retrieved from http://www.bbc.co.uk.news/world-africa. 
Chothia, F. (2012). Who are Nigeria's Boko Haram Islamists? BBC News. Retrieved from http:www.bbc.co.uk/news/world-africa-13809501.

Chothia, F. (2015, May 4). Who are Nigeria's Boko Haram Islamists? BBC Africa. Retrieved from http://www.bbc.com/news/world-africa-138095

CNN Library. (2015, April 21). Boko Haram fast facts. Retrieved from http://www.edition. cnn.com/2014/06/09/world/

Duddley, B. J. (1968). Parties and politics in northern Nigeria. London: Frank Cass and Co. Ltd.

Dudley, B. J. (1968). Parties and politics in northern Nigeria. London: Frank Cass.

FG not supporting Northern Gov's development efforts - US. (2014, May 2). The Punch.

Guttschuss, E. (2012). Understanding Nigeria's Boko Haram radicals. Retrieved from http://www.itinnes.org/Report/9325.html.

Harunah, H. B. (2002). Shariah under Western democracy in contemporary Nigeria: Contradictions, crisis and the way forward. Lagos: Perfect Printers.

Idowu, K. (2015, May 30). 13 killed as Boko Haram attacks Maiduguri again. Punch. Retrieved from www.punchng.com/news/

Katsina, A. M. (2011). Boko Haram, Nigeria and sub-regional security. Nigerian Journal of International Affairs, 3(37), 17-38.

Kilete, M. (2015, April 22). Military has turned tide against Boko Haram - FG. Daily Sun.

Kirk-Greene, A.H.M. (1965). Principles of native administration in Nigeria: Select Documents, 1900 - 1947. Oxford University Press.

Lubeck, P. (1986). Islam and urban labour in northern Nigeria: The making of a Muslim working class. Cambridge University Press.

Mohammed, A. (2015, February 5). 10 political parties reject calls for poll shift. Premium Times. Retrieved from http://www.premiumtimesng.com/news/176309-10

National Consortium for the Study of Terrorism and Responses to Terrorism, START. (2013). Country Reports on Terrorism 2012, 2013. US Department of State: Office of the Coordinator for Counterterrorism.

Nigerian's resolve to sack PDP irreversible, APC tells Jonathan. (2015, March 9). Daily Sun, p. 13.

Niger Reporters. (2015, June 11). Buhari meets regional leaders over a new anti-Boko Haram force. Retrieved from www. Nigerreporters.com.

Obama promises to help Nigeria in fight against Boko Haram. (2015,July 20). Transparent Nigeria. Retrieved from www.transparentnigeria.com/news_entries/18946.

Ochai, P. (2014). US Embassy's antidote to Boko Haram insurgency. The Economy. December 2014, p. 42.

Odebode, N., John Alechenu, Chukwudi Akasike, \& Oziora Ubabukoh. (2014, April 21). Presidency is arrogant, confused, Nyako insists. The Punch.

Ogbonnaya, O. (2011, September). Boko Haram is Battle for 2015, says Chukwumereije. The Nation newspaper. Retrieved from http://www.thenationalineng.net/2011/index. php/news/21270.html

Okoro, R. E. (2014). Terrorism and Governance Crisis: The Boko Haram Experience in Nigeria. African Journal on Conflict Resolution, 14(2), 103-127. 
Oladeji, B., \& Agbaji, G. (2011). Smoke out Boko Haram sponsors, Jonathan orders security chiefs. all Africa, December 30. Retrieved from http://allafrica.com/ stories/201112300822.html

Oladipo, T. (2015, May 7). Why Boko Haram remains a threat. BBC Africa. Retrieved from http://www.bbc.com/news/world-africa-32604782

Onah, E. I. (2014). The Nigerian state as an equilibrium of violence: An explanation of the Boko Haram insurgency in northern Nigeria. African Journal on Conflict Resolution, 14(2), 63-80.

Owuamanam, J., Olalekan, A., \& Bakam. A. (2015, January 23). Youths attack President's campaign team in Bauchi. Punch. Premium Times. (2014, May 17). Boko Haram has killed over 12, 000 Nigerians, plans to take over country, Jonathan says. Retrieved from http://www.premiumtimesng.com/news/160942

Sergie, M. A., \& Johnson, T. (2014). US Council on foreign relations. Retrieved from http://www.cfr.org/nigeria/boko-haram/p25739

Soriwei, F. (2015, March 17). B'Haram can't humiliate Nigerian army again - COAS. Punch, 12.

Sotubo, J. (2015, February 7). INEC postpones Nigeria 2015 General Elections for 6 weeks. Pulse. Retrieved from http://pulse.ng/politics/breaking-news

Suleiman, T. A. (2012, June-July). Conspiracy of silence. Tell Magazine.

Transparency International. (2014, May 18). Corruption perceptions index (several years). Retrieved from http://archive transperency.org/policy-research/survey-indices/cpi/

Udoidem, S. I. (1997). Religion and politics in Nigeria: A survey of religious-related crisis in Nigeria since independence. In Okafor, F. U. (Ed.). New strategies for curbing ethnic and religious conflicts in Nigeria. Enugu: Fourth Dimension Publication.

Whitaker Jr., C. S. (1970). The politics of tradition: Continuity and change in northern Nigeria, 1946 - 1966. Princeton, New Jersey: Princeton University Press.

Zounmenou, D., \& Kane, M. (2014, March 11). Nigeria's fight against Boko Haram: How can France help? ISS Today. Retrieved from http://www.issafrica.org/iss-today/html. 